\title{
Evaluating the effect of new working practices on office space usage in Hong
}

\author{
Kong \\ Wadu Mesthrige Jayantha \\ Olugbenga Timo Oladinrin
}

\section{Abstract}

Purpose

Many organizations in Hong Kong have witnessed a reduction in average space usage due to high occupancy costs. New working practices (NWPs) are viewed as a reform tool to manage expensive real estate around the world. However, it is unclear whether or not NWPs influence office space usage in business organizations in Hong Kong. This study, therefore, aims to evaluate if the average space reduction in office firms is caused by the NWPs in the finance, insurance, real estate, and business (FIREB) firms.

\section{Design/methodology/approach}

Twenty NWPs were initially derived from the extant literature. A questionnaire survey was conducted with listed FIREB firms in Hong Kong to assess the impact of the identified NWPs on space usage. The data collected from the questionnaire survey were analyzed using descriptive, explorative factor analysis (EFA), and partial least squares - structural equation modeling (PLS-SEM) to evaluate the effects of NWPs on average space usage.

\section{Findings}

Results revealed that four major NWP factors influence average space usage. Among these four factors, three of them "flexible arrangement", "multitasking knowledge workers", and "teamwork and communication" influence space usage positively. Even though the effect of the fourth factor "training and networking" was significant it does not reflect a positive influence on space usage. Business organizations can focus more on the implementation of NWPs to cushion the effects of the high cost of occupancy.

\section{Originality/value}

The research provides new knowledge to the limited literature on the effect of NWPs in FIREB firms and enriches the growing body of international literature on how today's competitive global business organizations should revisit their workplace strategies to accommodate the rising agile workforce and NWPs. The findings offer new insights into the ongoing debate on the impact of ICT-enabled NWPs on space usage. From the real estate perspective, the findings should inform policymaking towards the better planning ahead of office properties to accommodate NWPs, helping 
Hong Kong to remain competitive as a key financial centre.

Keywords- Workspace, New working practices, FIREB firms, Space usage, Hong Kong, PLS-SEM Introduction

Efficient use of office space resources is critical in the current competitive business era. While the duo of technological advancement and globalization have enhanced the expansion of the business sector, they have brought significant changes to office space usage patterns. These two influential drivers have brought about changes to the organizational structure of firms (Cattell, 2002; Harris, 2015) through new working practices (NWPs) such as teleworking, team-work, hot-desking and flextime (Haynes, Fawcett, \& Rigby, 2009; Rabianski \& Gibler, 2007). Laing, Craig, and White (2011) posited that using 20th-century spaces to do 21 st-century knowledge work will result in lost productivity, higher capital expenses, and difficulties in accessing managers. Some significant changes to the office workplace and space usage have been noticed over the last 2 decades (Harris, 2015). Recent research found that some technologydriven NWPs do exert an increasing impact on office space management by altering the way in which firms use space, e.g., more communal space rather than territorial offices (Dixon, Marston, Thompson, \& Elder, 2003; Harris, 2015; Miller, 2014). Hence, NWPs are the strategic modern flexible working practices, adopted by organizations to manage expensive real estate around the world (De Bruyne \& Beijer, 2015, Haynes et al, 2015, Harris, 2015).

The health of the finance, insurance, real estate, and business service (FIREB) sector is crucial to the economy of Hong Kong, not only because it brings foreign reserves as a pillar sector, but its healthiness reflects the status of the city as the largest, and dynamic, financial hub in the region. Hong Kong, however, is facing a threat from neighbouring cities in securing and attracting the world's most dynamic corporations and the best skills and in pulling in footloose capital. Hong Kong has the costliest office space in the world. Office occupancy costs in neighbouring cities such as Beijing, Shanghai, Guangzhou, and Singapore are considerably cheaper. According to Peggy (2016), many companies, are increasingly looking at their occupancy costs and workplace strategies and leaving CBDs to avoid high occupancy costs. Some firms were said to be even set to leave Hong Kong altogether because of high occupancy costs while some are surviving by shrinking their workspace. It has been established that workspace in most organizations in Hong Kong has shrunk from 100 sq. ft. per desk to 50-60 sq. ft. per desk (CBRE, 2015). To face today's highly competitive global business environment organizations in other parts of the world are increasingly revisiting their workplace strategies. It is postulated that high rental costs can be greatly offset by enhanced organizational efficiency brought about by NWPs. This raises the following question; do NWPs have influence on average space usage?. Harris (2015) claimed that the 
NWPs can significantly influence office space usage and space demand in business firms. This influence is clearly seen through changes in average space usage (Gibson, 2003). No other factor is as effective as average space usage in capturing the changing patterns of office space absorption (Miller, 2014). Thus, accurate assessment of future space demand greatly depends on how well-identified are the changes in work patterns and organizational structure, with their implications for average space usage. Obtaining relevant information about the new workplace strategies adopted by firms is key to a successful research outcome. It is, however, not clear whether the shrinking workplace in Hong Kong is connected to the adoption of NWPs.

Almost two-thirds of large organizations worldwide have embraced NWPs (Dixon \& Ross, 2011) mainly to reduce costs by sharing workplaces (Gorgievski, van der Voordt, van Herpen, \& van Akkeren, 2010). The extent to which NWPs have influenced office space usage, however, is still being debated, with no consensus on the impact on space usage. Some assert that NWPs alter the way in which firms use space, e.g. more communal space rather than territorial offices (Duffy, Laing, \& Crisp, 1993; Gibson \& Lizieri, 1999; Lizieri \& Satchell, 1997), indicating a reduction in average space usage. In contrast, some assert that the effect of NWPs on space usage is less dramatic than expected (De Paoli \& Ropo, 2015; Foo Sing, 2005; Gibson, 2001; Malhotra, Majchrzak, $\&$ Rosen, 2007). However, research has shown that a slight variation in average space usage can still have a great impact on space demand (Romijn, Hakfoort, \& Lie, 1996). Apparently, the empirical evidence of the effects of NWPs on office space usage is meager (Foo Sing, 2005; Lizieri, 2003; Virginia \& Colin, 2001). This study, therefore, presents an analysis of NWP factors which are critical to the probable reduction in office space usage in the FIREB firms in Hong Kong. This study is the first to explore the effects of NWPs on space usage in Hong Kong.

\section{Background of the office workspace management}

The concept of office space was rare in medieval eras, as most people worked from home, but a turning point was noticed in the 17th century when professionals began to work from offices in places like Amsterdam, London, and Paris. Hence, a cultural distinction was drawn to differentiate between the office as a workplace, and the home, as a place of comfort, privacy, and intimacy (Rybczynski, 1986). The office is more than just a place, but rather a strategic resource that can enable and sustain organizations to achieve competitive advantage and maintain operational efficiency (Khamkanya, Heaney, \& McGreal, 2012). Efficient use of resources, especially space, is crucial as business organizations use space to enhance their profitability (Hills \& Levy, 2014). However, organizational workplace and workspace are continuously evolving and transforming even as the business itself is changing. The origins of the modern office could be traced to the middle of the nineteenth century as a response to the industrial 
revolution that triggered a significant increase in information-related problems and demanded a measure of control which was unavailable at that time (Bradley, 2007). As businesses began to feel the pressures to gain and sustain the competitive position, needs arose to develop new work practices such that managers of workspace moved away from their reactive traditional focus to a strategic and proactive way of managing space (McGregor, 2000).

Dramatic changes that took place at the inception of alternative office strategies during the early 90s, made workspace managers speculate non-existence of office in the year 2000 (Madsen, 2001). While companies began to redesign their office spaces to accommodate new working practices such as teamwork and teleworking, it was not certain whether office space was a cultural revolution or just a mere cost-cutting (Meyer 1997). Consequently, the evolvement of the NWPs has revolutionized office space toward downsizing, for the purpose of shrinking occupancy costs and enhancing workers' productivity (Tagliaro \& Ciaramella, 2016). Hence, there has been a global trend characterized by less assigned space and more shared space for employees towards a higher occupational density (Hills \& Levy, 2014). Because of space crunch, shrinking office sizes is prominent in Europe (such as Germany, France and Switzerland) and Asia (especially, Singapore, Hong Kong, Japan, Korea and Taiwan) compared to the US where most office spaces are still above the BOMA international density recommendation of 225 square feet per person (Knapp, Vickroy, de Bruyn, \& Kwong, 2009).

An assertion by McGregor (2000) that work will no more be a place, but an array of activities that can be practically undertaken anywhere and at any given time calls for attention on the paradigm shift that could revolutionize office space management. There has been an argument as to whether the types of workspace design (such as hive, cell, den, and club; see Haynes (2008)), helps or hurts performance within an organization (Waber, Magnolfi, \& Lindsay, 2014). Some studies revealed negative effects of new office workspace arrangement such as open-plan offices (Ali, Chua, \& Lim, 2015; Binyaseen, 2010; Smith-Jackson \& Klein, 2009) while some studies emphasized the benefits of such arrangement (Chilton \& Baldry, 1997; Waber et al., 2014). However, a recent study by Gerdenitsch, Korunka, and Hertel (2018) revealed that the effects of some changes in workspaces on office workers are still unclear. Although the study of space management from an organizational perspective is highly valued, interest in organizational studies concerning the value of space management is generally lacking (Skogland \& Hansen, 2017). Hence, the misallocation of workspaces has been identified (Binyaseen, 2010) which invariably affects employees satisfaction and productivity. Despite the shrinking workspace in Hong Kong, it is evident that most of the studies that raised concerns about NWPs were conducted outside Hong Kong, hence, the study in this context is timely. 


\section{Influence of NWPs on space usage in the FIREB Sector in Hong Kong}

The rapid expansion of the FIREB sector in Hong Kong over the last two decades can be attributed to two major forces, in addition to the structural changes in the economy: (i) globalization of the real estate market; and (ii) rapid usage of information and communication technology (ICT). In the last two decades, globalization of service sector activities, in particular, sub-sectors of the real estate industry such as brokerage firms, real estate finance firms, investors, and builders have been active players in this global surge (Bardhan \& Kroll, 2007). Influential forces which have led to this transformation include (a) technological changes, (b) rapid opening up of formerly closed economies (e.g. China), (c) and the liberalization of some big financial markets (Bardhan \& Kroll, 2007). From the demand side, the largest occupiers of office space, multinational companies, are becoming rapidly global. For example, Hong Kong has become the premier location for many regional headquarters and regional offices for multinational companies. The number of regional headquarters and regional offices in Hong Kong representing parent companies located outside Hong Kong has increased 3,955 as of June 2018 (Census and Statistics Department, 2018). At the same time, expansion of the FIREB sector has been accelerated by the advance of ICT. Barras and Clark (1996) note that the FIREB sector has been in the vanguard of the ICT revolution. While ICT and globalization have accelerated the expansion of the FIREB sector, they have brought significant implications to office space usage patterns. These two influential drivers have brought about changes to the organizational structure of firms (Harris, 2015; Cattell and Locket, 2002) through NWPs such as team-working, hotdesking and home-working (Haynes, 2007; 2008; Rabianski and Gibler, 2007). These fundamental changes are taking place at a time when competitiveness and cost efficiency is paramount for organizations (Joice and Gill, 2006). The literature on the influence of NWPs on real estate is seen scattered under various topics of interest such as internal configuration, changing business practices, core versus non-core space, activity-based offices, leasing structures, building services and amenities. Dixon (2005) provides a detailed discussion of these issues. Though numerous goals are cited in the literature underlying the adoption of ICT-induced NWPs, two important groups can be broadly identified: (1) operational cost reduction via reduced space usage and (2) enhancement of business performance (enhance employee productivity, better utilization of space and resources). The NWP influence on office space usage and space demand significantly is being felt across business firms (Harris, 2015), and this influence is clearly seen through changes in average space usage (Gibson, 2003). No other factor is as effective as ASPP in capturing the changing patterns of office space absorption (Miller, 2014). As a dynamic demand parameter, the influence of NWPs on 
average space usage must be estimated accurately (Liang \& Kim, 1998; Miller, 2012). Thus, a comprehensive and rigorous study is required to identify the key working pattern and organizational changes occurring in office firms in order to assess future space needs more accurately. Especially, those changes need to be accurately understood.

Existing scholarship has generated important insights in the West on how different aspects of NWPs influence different organizational goals. However, whether NWPs are really being implemented in Asian organizations, and if so, in what ways, NWP influences space usage, remain largely under-explored. In fact, a study of this nature in Hong Kong has never been made. The only available recent study, by Sing (2005), investigated whether the space reduction effects of ICT have been significant in the Singapore office market. This study, however, incorporated no NWP elements in the analysis. Moreover, there is no clear consensus about the effects of NWPs on space usage among the past studies reviewed above. This has limited the pursuit of a better understanding of the impact of NWPs on space usage patterns and other organizational goals. In undertaking to provide a rigorous analysis to evaluate the key NWPs related factors affecting space usage, this study makes a timely contribution to filling the gap. This work is needed for two reasons. First, since there is a significant difference in ideologies and cultures between the west and the east, it cannot be assumed that NWPs in the west are appropriate for the east (interested reader should check Qingxue (2003) for more information on cultural diversity between the west and the east). Especially, when culture plays a pivotal role in determining the success of NWPs and there is some occupier resistance to the concept (Crosby, Gibson, Lizieri, \& Ward, 1998). Second, if Hong Kong is to maintain its international financial centre status, it is paramount to understand the factors influencing space usage which are also required to enhance business performance as firms now face intense competition from other emerging cities.

\section{Methodology}

This research adopted an explorative approach to determine a set of NWP factors that influence space usage in FIREB firms. The methodology involves a review of extant literature to identify factors that define NWPs; a questionnaire survey with listed FIREB firms in Hong Kong to assess the identified NWP factors. The collected survey data were analyzed by using an explorative and modeling techniques that are capable of estimating complex cause-effect relationship with latent variables; in order to identify the critical factors that impact space usage.

\section{Questionnaire survey}

An in-depth review of the academic literature and other publications was carried out to 
identify changes in working practices experienced in some developed countries around the world within office occupying firms. In total, 20 factors related to NWPs and office space usage were identified from the literature as shown in Table 1. A questionnaire was drawn up from the 20 NWP factors derived from the literature review. A slight modification was performed on the questionnaire based on comments of 5 seasoned academics with regards to the clarity of the factors, structure, and length of the questionnaire (Oyedele, 2012). The aim of the survey questionnaire was to garner firmspecific perceptual rankings from FIREB sector. The questionnaire sought information on change attributes, such as the nature of working patterns and the nature of dynamic use of office space. The questionnaire has two sections. First, demographic characteristics were collected including respondent position status, job type (e.g. administrative or technical), office type (e.g. closed or open), and years of experience. This allows correlations between the diverse demographic characteristics of respondents and the identified NWPs. Second, questions seeking opinions on the impact of the identified NWPs on office space usage (on a five-point Likert scale). In the study, NWP factors refer to factors that describe new ways of working in modernday firms. The questionnaire was also used to collect data on average workspace per person in the respondents' firms, using the following range: $\square 1-20$ sq. ft.; $\square 21-50$ sq. ft.; $\square$ 51-100 sq. ft.; $\square$ 101-120 sq. ft.; $\square$ more than 120 sq. ft.

\section{Please insert Table 1 here}

According to the Hong Kong Stock Exchange (2017), there are 279 Finance, Insurance, Real Estate and Business-services (FIREB) listed firms in Hong Kong; and another 285 FIREB listed (elsewhere) firms (Insuarnce Authority, 2017) have offices in Hong Kong, making the total listed FIREB firms 564. Using Slovin's Formula (Ellen, 2018), 235 sample size was derived. In addition to opinions and comments from senior academic in the field, a pilot study of four firms (one for each sub-category), prior to administering the final survey, was made for fine-tuning. For the firms that have several branches located across Hong Kong, data were collected only from the head branch/office. A paper-based questionnaire survey (supported by an online survey) was used. Following Lee and Brand (2005), a voluntary response survey approach was adopted in collecting data from the firms. A firm was responsible for filling one questionnaire. This approach was used in a similar study (Minbaeva, 2005). The paperbased questionnaire was sent to the firms with the help of 2 Research Assistants trained for the survey. An email-based questionnaire survey and SurveyMonkey-based link were sent to the firms that were difficult and not economical to reach to collect the data within a short time frame and to increase the response rate of the survey (Yu \& Shen, 2013). Eventually, after a round of reminders, 105 out of the 235 firms returned the 
filled questionnaire, representing 45 per cent overall response rate. This is favourably considered satisfactory as Fellows and Liu (2003) recommended a minimum response rate of 30 per cent from a minimum sample size of 107. Table 2 summarizes the respondents' background information. Out of the 105 responses, 66.7 per cent were professional staff, 12.4 per cent were divisional head and above, 2.9 per cent were technical staff, 8.6 per cent were clerical staff, and 9.5 per cent represented others. Of all the respondents, about 66 per cent had over 10 years of working experience in their respective fields. This indicates that the information provided by the representatives of the firms could be relied upon. The distribution of the returned surveys showed that 33.3 per cent of the total responses were retrieved from finance firms, 3.8 per cent from insurance firms, 43.8 per cent from real estate firms, and 19.0 per cent from business and consultancy service. Majority of the respondents (42.9 per cent) indicate that open office with limited or no partitions are common in their firms.

\section{Please insert Table 2 here}

\section{Data analysis and results}

\section{Descriptive statistics of NWP factors}

The mean scores, standard deviation (S.D) and standard error (S.E) of the impact of NWPs on space usage are presented in Table 3. The 'flexible working arrangement' has the highest mean score of 3.74, followed by 'job autonomy' (3.70), 'various meeting spaces' (3.680, and 'telecommuting/telework' (3.60). S.D and S.E of the sample mean reflect how symbolic a sample is likely to be to the population (Ahadzie, Proverbs, \& Olomolaiye, 2008; Field, 2005). A relatively small S.E is a reflection that most sample means and the population mean are similar or that there is consistency among the means of different samples (Field, 2005). Given that the associated S.E with the means in this study are relatively close to zero, it can be inferred that the chosen sample flawlessly reflects the population (Table 3). However, the values for S.D are above 1.0, suggesting that the respondents interpreted and rated the factors differently (Ameyaw \& Chan, 2016).

\section{Please insert Table 3 here}

\section{Exploratory Factor Analysis (EFA)}

As the main aim of this study is to assess the effect of NWPs on space usage, EFA technique was adopted to identify the underlying latent factors, using Statistical Package for Social Sciences (SPSS) 23.0. This technique is applicable in this case 
because of a lack of a priori knowledge about the factor structure (Field, 2005). According to Williams, Brown, and Boyle (2012), EFA is a statistical tool used to compress large-scale data set into a smaller number and manageable set of variables and explain the underlying dimensions between observed/measured variables and latent/unobserved constructs. EFA was performed to simplify the structure of the NWP data set so as to explore the features of NWPs in FIREB firms. Following insights from Atkinson-Palombo and Kuby (2011), EFA was applied to reduce the 20 factors related to NWPs and office space usage to only a few distinct group factors. The group factors formed by the EFA provide a basis for establishing latent constructs to examine the influence of NWPs on space usage. The suitability of data for factor analysis is determined by a sample-to-variable ratio with a common threshold of 1:5 (Lingard \& Rowlinson, 2006), that is, one variable to 5 subjects/respondents. The variable-tosubject ratio in this study is above the recommended threshold, hence, the data is suitable for EFA.

The appropriateness of using EFA for factor extraction was tested through the parameters shown in Table 3. The values of the test statistic for Kaiser-Meyer-Olkin (KMO) Measure of Sampling Adequacy was 0.828, which exceeds the recommended threshold of 0.50 (Norusis, 2003), indicating that EFA was appropriate. The Bartlett's test of sphericity has a large value of 1166.276, and the associated significance was

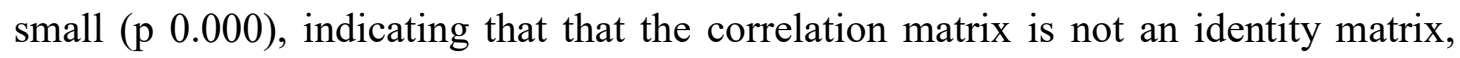
which further suggests the appropriateness of factor analysis (Norusis, 2003). To determine the significance of factor loadings, the values of 0.3-0.4 could be accepted as a minimal level (Hair, Anderson, Babin, \& Black, 2010). The results of the analysis show that all the loadings were above the cut-off value and were therefore retained. Most of the factors have high factor loadings, which further lend support to the appropriateness of the sample size (Ahadzie et al., 2008). Because the factor-based estimation in SPSS only focuses on the construct, the details of factor loading are not presented in this section, rather, it will be presented in the next analysis in which the factor loadings are determined from the model estimation of composites. Using principal component analysis (PCA), the correlation matrix of the 20 factors produced a four-factor solution with varimax rotation and eigenvalues greater than 1.0, explaining 64.9 per cent of the total variance. The four principal factors and their associated factors are interpreted as follows:

- Factor 1: Flexible arrangement;

- Factor 2: Training and networking;

- Factor 3: Teamwork and communication; and

- Factor 4: Multitasking knowledge workers. 


\section{Partial Least Square Structural Equation Model (PLS-SEM)}

There are various techniques for analyzing the relationship between a given set of variables in the literature such as Multiple regression analysis (MRA), Path analysis (PA), and Structural equation modeling (SEM), of which SEM is increasingly used (Norman \& Streiner, 2003). Two different methods can be used for SEM analysis; (1) Covariance-based (CB-SEM and (2) Component-based using partial least square estimation (PLS-SEM) as described by Haenlein and Kaplan (2004). However, it was discovered that recent research has moved beyond the CB-SEM versus PLS-SEM contest (Rigdon, 2012; Rigdon, Sarstedt, \& Ringle, 2017), by confirming PLS-SEM as a distinct approach for analyzing composite-based path models (Hair, Risher, Sarstedt, \& Ringle, 2019). In this study, the authors employed PLS-SEM approach that is fast becoming a tool of preference for researchers in the social sciences as a multivariate technique for non-experimental and experimental data (Aibinu \& Al-Lawati, 2010). PLS-SEM is a non-parametric method used to estimate causal relationships by indirectly measuring latent constructs using associated survey indicators (Memon, Rahman, Aziz, \& Abdullah, 2013). PLS-SEM is preferably employed in this study because of its suitability for exploratory analysis and developmental theory testing (Lowry \& Gaskin, 2014). Two stages are involved in PLS-SEM analysis, (1) evaluation of the structural (inner) model and (2) the measurement (outer) model (Henseler \& Sarstedt, 2013; Memon et al., 2013). In evaluating PLS-SEM results, the measurement model was examined first. Having satisfied all the required criteria for the measurement model, the structural model was then assessed, using some established rules of thumb in the literature (Hair et al., 2019; Hair Jr, Hult, Ringle, \& Sarstedt, 2017). The stepwise process of the analysis is discussed in the following section.

\section{Assessment of measurement models}

Given that the model involved in this study is a reflective measurement model, the first step in evaluating the model is by examining the factor loadings and cross-loadings. The essence of this is to detect problems (if any) with any of the observed variables. Table 5 shows the loadings and cross-loadings of indicators in their corresponding constructs. At this stage, convergent validity was determined by examining the measurement scale to see if all the items are loaded above the threshold value of 0.50 on their associated constructs, and if there is any cross-loading of items i.e. any item loading higher on other constructs more than the construct it supposed to measure (Hair et al., 2010; Ho \& Oladinrin, 2016). The result of the preliminary analysis showed that one item (NWPI7) loaded below the threshold score (0.5), and was removed from the analysis. Other six items loaded on more than one factor (cross-loading), indicating that 
a simple structure has not been achieved. Therefore, to appropriately allocate items to factors, cross-loading items were removed as recommended in the literature (Watson \& Thompson, 2006). The items that exhibited cross-loadings include NWPI5, NWPI12, NWPI13, NWPI16, NWPI19, and NWPI20. The justification for removing these items was because they contribute little to the clarity of the underlying dimensions that are being sought and their removal eventually made a significant improvement in the measurement model (Watson \& Thompson, 2006). However, the PLS-SEM analysis was rerun after removing the problematic items (Ferguson \& Cox, 1993). In the analysis, all the items loaded higher (above 0.50 ) on their corresponding constructs (Hair et al., 2010) and all the items there were retained loaded on their mother constructs from a lower range of 0.542 to an upper range of 0.992 . All the items loading on putative factors are presented in Table $\mathbf{5}$ in order to avoid masked cross-loading and to strengthen the case for the published factor structure (Watson \& Thompson, 2006).

\section{Please insert Table 5 here}

The second step in evaluating the measurement model is assessing internal consistency reliability, which is most often achieved by composite reliability, with higher values generally indicating higher levels of reliability (Hair et al., 2019). The values of composite reliability depicted in Table 6 range between 0.759 and 0.901 which is above recommended threshold of 0.70 and 0.90 for a range from "satisfactory to good" (Hair et al., 2019, p. 8). Cronbach's alpha can also be used to measure the internal consistency reliability with similarly recommended thresholds however, it exhibits unweighted items, produces lower values, and gives a less precise measure of reliability than composite reliability (Hair et al., 2019). The third step is assessing the convergent validity of each construct which is measured the average variance extracted (AVE). generally, the AVE reflects the extent to which each construct converges to clarify the variance of its items (Hair et al., 2019). The values for AVE range between 0.527 and 0.715, which above the threshold for an acceptable AVE of 0.50 . The results indicate that each construct explains more 50 per cent of the variance of its items.

\section{Please insert Table 6 here}

The fourth step is to determine the extent to which a construct is empirically distinct from other constructs in the structural model which is the discriminant validity. Table 7 presents the results of the discriminant validity (using Fornell-Larcker Criterion). To assess the discriminant validity, the square root of the AVE coefficients was used to replace the correlation matrix along the diagonal line (Fornell \& Larcker, 1981). 
Normally, the squared AVE (i.e. the diagonal coefficients) should have greater values than the off-diagonal coefficients in the corresponding columns and rows (Hair, 2006). The results signify the highest square roots of AVE for "Multitasking knowledge workers" (0.846) and lowest for "Training and selective hiring" (0.726). Since the shared variances for all the constructs are lesser than their AVEs, the discriminant validity has been duly provided.

\section{Please insert Table 7 here}

\section{Assessment of structural models}

Having satisfied the measurement model assessment, the next phase was the assessment of the structural model. Two major assessment criteria were considered, including the coefficient of determination $\left(\mathrm{R}^{2}\right)$ and the statistical significance and relevance of the path coefficients. Prior to the assessment of the structural relationships, collinearity was examined to ensure that the relationship does not bias the partial regression results. The collinearity issue is examined through the variance inflation factor (VIF), which is automatically generated by the SMART-PLS software. The VIF values should ideally be lesser than 3 for a non-collinearity outcome. The values of the VIF range between 1.196 and 1.799 indicating that there is no collinearity issue. The $\mathrm{R}^{2}$ value of the structural model is 0.109 , indicating that the regression of the four independent latent constructs (NWPs) is relatively low, explaining about 11 per cent of the variance in reduction in the space usage. On the whole, the combination of all the four group NWPs has predictive ability for 11 per cent of changes in average space usage in FIREB firms. The value of $R^{2}(0.109)$ is acceptable because $R^{2}$ is a function of the research context and the number of predictor constructs. In the context of this study, larger $\mathrm{R}^{2}$ value was not anticipated since the reduction in office space in the context of Hong Kong depends on other factors than NWPs. More so, the model only has four predictor constructs. $\mathrm{R}^{2}$ value as low as 0.10 is considered satisfactory depending on the context of the study (Hair et al., 2019). The final step in assessing structural model is to evaluate the statistical significance and relevance of the path coefficients by running bootstrapping in SMART-PLS. The path coefficients measure the structural relationship between predictor/latent constructs (NWPs) and average space usage. Figure 1 depicts the values of structural path coefficients and Table 8 shows the level of significance of each path. The results reveal that 3 constructs (i.e. flexible arrangement, multitasking knowledge workers, and teamwork and communication) have positive correlations with average space usage but none of them has a significant impact. This implies that the presence of these NWPs supports the reduction in space usage with minimal influence. However, 'training and networking' exerts a significant negative impact on average space usage, suggesting that this NWP contribute to increasing average space usage. 


\title{
Please insert Table 8 here
}

\author{
Please insert Figure 1 here
}

\section{Discussion of results}

\section{Flexible arrangement}

This factor consists of four measurement items: flexible working arrangement, job autonomy, telecommuting/teleworking, and staff density. Achieving a flexible arrangement that can influence average space usage is closely linked to telecommuting/teleworking (NWPI3) having the highest loading of 0.951. Generally, telecommuting or teleworking, as they are interchangeably used, describe employees that work away from the office (Berube Kowalski \& Swanson, 2005). When employees are allowed to work at home, at the client's office or on-the-move, as the case may be, there will more possibility to reduce workspace within an organization. This finding agrees with Lim and Teo (2000) who posited that teleworking is one potential way to economize office space usage. Job autonomy $(0.825)$ is an important factor in average space usage. The commitment of the firms to job autonomy can enhance office space utilization. This can be true because the use of mobile IT enables job autonomy to intertwine with private and work schedules as well as procedures (Köffer, Junglas, Chiperi, \& Niehaves, 2014). Flexible working arrangement (e.g. part-time, flexitime, overtime) is another practice that fosters economic utilization of office space as Skyrme (1994) claimed that flexible working supports building a lean and responsive organization. Management of staff density $(0.765)$ is another practice that influences average space usage. Previous research revealed that occupant density affects the cost of space in the office setting (Saari, Tissari, Valkama, \& Seppänen, 2006).

\section{Training and networking}

The mean scores of the three measurement items associated with this factor (training: mean score $=3.14$; networking: mean score $=3.07$; selective hiring: mean score $=$ 2.81) are quite low and suggest that 'training and networking' is not particularly contributing to reduction in office space. However, this study shows that 'training and networking' cast the greatest influence on the average space usage given the highest significant but negative path coefficient $(-0.361)$. This suggests that the current states of training, networking, and selective hiring in FIREB firms in Hong Kong, are negatively influencing average space usage. Thus, these items are probably contributing 
to an increase in space usage. This could be as a result of the insufficient or inappropriate implementation of these practices. For instance, insufficient training has been identified as a barrier to the alternative use of space (Pugsley \& Haynes, 2002). A past study also revealed that employers use personal networks in selective hiring in order to save time and cost (Neckerman \& Kirschenman, 1991). Such practice may result in a mismatch of the employees against the purpose of efficient space usage. To enhance new ways of working, Virginia Gibson (2003) suggested that employers should be flexible in the way they hire and manage employees. Hence, more productive and effective space usage can be achieved by sufficient training of the employees to maximize the value of technology, coupled with appropriate networking and selective/purposive hiring.

\section{Teamwork and communication}

This factor group comprises four NWP factors: teamwork, flexible workspace, improved communication, and ad-hoc task-forces. It is the second factor with high path coefficient in the structural model (0.233), implying that it influences the reduction in average space usage. This is consistent with historical trends. Effective teamwork and communication among employees have long been used to support the transition from traditional office practice to NWP (Virginia Gibson, 2003). NWPs involves encouraging and giving autonomy to employees to undertake work in a team, at the most appropriate location (including sharing of the workspace), with readiness to communicate their opinions. With the advent of information technology, teams in organizations nowadays are virtual in nature and these virtual teams are underpinned by effective communication strategy (Gillam \& Oppenheim, 2006). In the study of 2,500 employees of a company, Arge and Landstad (2004) found that the combination of a flexible workplace, a more flexible, project and team-based work mode, supported by new ICT platform, is highly beneficial to the organization in terms of knowledge sharing, learning, co-operation, and innovation. This finding also agrees with De Paoli, Arge, and Hunnes Blakstad (2013) who revealed that the rapid emergence of project work has made NWPs possible and the cost efficiency perspective has been a major argument (at least, from facility management viewpoint) for advancing flexible workspace solutions.

\section{Multitasking knowledge workers}

This factor has two NWP factors including 'multitasking' and 'knowledge workers'. This factor lends support to previous findings (Blosser, Slaughter, Scherlen, \& Matthews, 2001; Davies, 2005; Greene \& Myerson, 2011) that multitasking and knowledge workers can influence space management in the workplace. The workflow in today's technology era has become less linear and incorporates multiple tasks 
performed by an individual, at a single workstation, instead of performing different tasks at separate terminals by multiple employees. This is consistent with Blosser et al. (2001) who emphasized the effective organization of workspace. The transformation in the world of work from an industrial economy to a knowledge-based has fostered a necessary change in the design of the office workspace. Firms are encouraged to design office spaces to support knowledge work (Peponis et al., 2007).

\section{Average space usage}

The re-invention that is currently taking place in workplaces is fostering the evolvement of a number of strategies (such as NWPs), being supported by information technological development. While these strategies avail the FIREB firms the opportunity to adopt a suitable solution to address particular needs, the focus is majorly to reduce associated cost by reducing office workspace. NWPs, in turn, has brought changes to corporate office space usage patterns in terms of workspace per person. This study explores the impact of NWPs on average space usage. Organizations are currently under pressure to drive down operation costs by reducing the space per workstation. It has been established that workspace in most organizations in Hong Kong has shrunk from 100 sq. ft. per desk to 50-60 sq. ft. per desk (CBRE, 2015). A continuous reduction of workspace, however, is not sustainable as it will, after a point, negatively affect employee and organizational productivity. Given that the predictive power of the model in this study is low (0.109), it is not surprising because of the nature and the context of the study area. There are other factors responsible for shrinking office space in Hong Kong such as limited land space, high density, and high rent (Wadu Mesthrige, 2014). For instance, office spaces are likely to shrink as rents soar.

\section{Conclusion}

In this era of technological advancement, workspace management is more vital than ever, especially with the increasing usage of NWPs in business organizations. The aim of this study was to evaluate the influence of NWP factors on space usage in FIREB firms in Hong Kong. Twenty (20) NWP factors were identified from the extant literature and were subjected to factor analysis to establish their underlying relationships. Four critical NWP factors that are influencing a reduction in average space usage were established. The effects of three of these factors consisting of "flexible arrangement", "multitasking knowledge workers", and "teamwork and communication" on the average space usage, was found to be positive. The effect of the fourth factor "training and networking" was significant but this factor does not reflect a positive influence on space usage. This may be as a result of redundant space created for training in some FIREB organizations. It is therefore recommended that, unless a designated space is fully engaged for frequent training, organizations should consider hiring a suitable 
training venue or use virtual training instead. These results, to some extent, support previous arguments about whether NWPs contribute to the reduction in space usage or not. The study provides a better understanding of the effect of implementing NWPs on space usage. It is therefore recommended that management of the FIREB firms pay particular attention to embracing NWPs. The firms stand to benefit from judicious and productive use of limited space if these NWPs are effectively embedded and given continuous management attention.

This study might not have captured a complete list of all the possible NWP factors that might influence space usage, however, the convergence with the literature gives confidence in the findings, and for some specific firms in a particular country, there would be distinct factors that should be added to the identified NWPs. For instance, some of the factors removed in this study might be retained to support the practices in different fields or locations. Thus, the methodology employed in this study is flexible permitting addition and removal of individual NWPs as new significant NWPs emerge or when the current NWPs become less relevant over time. With these useful findings, interested researchers may apply both the methodology and factors to explore the impact of NWPs in a different context. Such research would allow for a comparison to establish any differences and similarities in the NWPs. The impact of any NWPs on the office workspace may depend more on the nature and location of the work. Therefore, future research should endeavor to separate different types of works and their respective locations. In addition, the study has not tested any financial and productivity advantage of NWPs for the FIREB sector. Further research can dig deeper on the financial and productivity angle as well as the challenges and risks of shrinking office workspace with regards to the job and social security and ethical consideration in FIREB organizations.

\section{References}

Ahadzie, D., Proverbs, D., \& Olomolaiye, P. (2008). Critical success criteria for mass house building projects in developing countries. International Journal of project management, 26(6), 675-687.

Aibinu, A. A., \& Al-Lawati, A. M. (2010). Using PLS-SEM technique to model construction organizations' willingness to participate in e-bidding. Automation in Construction, 19(6), 714-724.

Ali, A. S., Chua, S. J. L., \& Lim, M. E. L. (2015). The effect of physical environment comfort on employees' performance in office buildings: A case study of three public universities in Malaysia. Structural Survey, 33(4-5), 294-

Ameyaw, E. E., \& Chan, A. P. (2016). Critical success factors for public-private partnership in water supply projects. Facilities, 34(3/4), 124-160.

Arge, K., \& Landstad, K. (2004). Arbeidsmiljøundersøkelse for Telenor på Fornebu. 
Byggforsk, Norges Byggforskningsinstitutt, Oslo.

Arvanitis, S., Seliger, F., \& Stucki, T. (2016). The relative importance of human resource management practices for innovation. Economics of Innovation and New Technology, 25(8), 769-800.

Askenazy, P., \& Caroli, E. (2010). Innovative work practices, information technologies, and working conditions: Evidence for France. Industrial Relations: A Journal of Economy and Society, 49(4), 544-565.

Atkinson-Palombo, C., \& Kuby, M. J. (2011). The geography of advance transitoriented development in metropolitan Phoenix, Arizona, 2000-2007. Journal of Transport Geography, 19(2), 189-199.

Bardhan, A., \& Kroll, C. A. (2007). Globalization and the real estate industry: issues, implications, opportunities. Retrieved from University of California, Berkeley:

Barras, R., \& Clark, P. (1996). Obsolescence and performance in the Central London office market. Journal of property valuation and investment, 14(4), 63-78.

Bayo-Moriones, A., Billon, M., \& Lera-López, F. (2017). Are new work practices applied together with ICT and AMT? International Journal of Human Resource Management, 28(4), 553-580.

Bean, C. J., \& Hamilton, F. E. (2006). Leader framing and follower sensemaking: Response to downsizing in the brave new workplace. Human Relations, 59(3), 321-349.

Bell, S. M., \& Anderson, M. (1999). Workplace solutions. Journal of Corporate Real Estate, 1(4), 349-360.

Berube Kowalski, K., \& Swanson, J. A. (2005). Critical success factors in developing teleworking programs. Benchmarking: An International Journal, 12(3), 236249.

Binyaseen, A. M. A. (2010). Office layouts and employee participation. Facilities, 28(7), 348-357.

Blok, M. M., Groenesteijn, L., Schelvis, R., \& Vink, P. (2012). New ways of working: does flexibility in time and location of work change work behavior and affect business outcomes? Work, 41(Supplement 1), 2605-2610.

Blosser, J., Slaughter, P., Scherlen, A., \& Matthews, P. J. (2001). Sink or swim: Organizing your work space is a lifesaver. The Serials Librarian, 40(3-4), 375380 .

Bradley, D. A. (2007). From Wooton to workstation: Mechanisms of the visible in office spaces. Journal for Cultural Research, 11(4), 359-369.

Cattell, K., \& Lockett, N. (2002, 18th - 20th September 2002). The effect of information and communication technologies on workplaces in South Africa. Paper presented at the Proceedings of the CIB W070 2002 Global Symposium, Glasgow. 
Cattell, K. S. (2002). Foresight, space and e-commerce. Facilities, 20, 145-162.

CBRE. (2015). Workplace Density in Hong Kong May Impair Staff Productivity and Performance. Retrieved from https:/www.cbre.com.hk/en/about/mediacentre/workplace-density-in-hong-kong-may-impair-staff-productivity-andperformance

Census and Statistics Department. (2018). Companies in Hong Kong with Parent Companies Located outside HK, The Government of the Hong Kong Special Administrative. Hong Kong Retrieved from https://www.censtatd.gov.hk/hkstat/sub/so360.jsp

Chilton, J. J., \& Baldry, D. (1997). The effects of integrated workplace strategies on commercial office space. Facilities, 15(7-8), 187-194.

Colteryahn, K., \& Davis, P. (2004). 8 trends you need to know now. $T$ and D, 58(1), 28 36.

Cristini, A., Gaj, A., Labory, S., \& Leoni, R. (2002). New work practices in Italy. Adoption and performance effects. Bergamo, Dipartimento di Scienze economiche Hyman P. Minsky, Università di Bergamo, febbraio, mimeo.

Crosby, N., Gibson, G., Lizieri, C., \& Ward, C. (1998). Market views on changing business practice, leases and valuation. RICS, London. ASB, London.

Davies, H. (2005). Productivity and the knowledge worker. Paper presented at the Conference proceedings: The Queensland University of Technology Reasearch Week International Conference.

De Bruyne, E., \& Beijer, M. (2015). Calculating NWoW office space with the PACT model. Journal of Corporate Real Estate, 17(2), 122-133.

De Paoli, D., Arge, K., \& Hunnes Blakstad, S. (2013). Creating business value with open space flexible offices. Journal of Corporate Real Estate, 15(3/4), 181-193.

De Paoli, D., \& Ropo, A. (2015). Open plan offices-the response to leadership challenges of virtual project work? Journal of Corporate Real Estate, 17(1), 6374.

Dixon, M., \& Ross, P. (2011). Vwork: Measuring the Benefits of Agility at Work: a Research Study: Unwired Ventures Limited.

Dixon, T. (2005). The impact of information and communications technology on commercial real estate in the new economy. Journal of Property Investment \& Finance, 23(6), 480-493.

Dixon, T., Marston, A., Thompson, B., \& Elder, B. (2003). eBusiness and the City of London office market. Journal of Property Investment \&amp; Finance, 21(4), 348-365.

Duffy, F., Laing, A., \& Crisp, V. (1993). The responsible workplace: The redesign of work and offices: Butterworth-Heinemann.

Ellen, S. (2018). Slovin's Formula Sampling Techniques. In: Fort Worth: Dryden Press. 
Eriksson, T. (2003) The effects of new work practices: Evidence from employeremployee data. In: Vol. 7. Advances in the Economic Analysis of Participatory and Labor-Managed Firms (pp. 3-30).

Fellows, R., \& Liu, A. (2003). Research methodology for construction (2nd ed.): Blackwell publishing, Oxford.

Ferguson, E., \& Cox, T. (1993). Exploratory factor analysis: A users' guide. International journal of selection and assessment, 1(2), 84-94.

Field, A. (2005). Discovering Statistics Using SPSS:(And Sex, Drugs and Rock 'n'Roll), ; ISM Introducing Statistical Methods. In: London: SAGE Publications.

Fincke, I., Harth, V., \& Mache, S. (2018). Working conditions in innovative office concepts under health-relevant and ergonomic aspects. Zentralblatt fur Arbeitsmedizin, Arbeitsschutz und Ergonomie, 68(3), 168-176.

Foo Sing, T. (2005). Impact of information and communications technology on real estate space: perspective of office occupiers. Journal of Property Investment \& Finance, 23(6), 494-505.

Fornell, C., \& Larcker, D. F. (1981). Evaluating structural equation models with unobservable variables and measurement error. Journal of marketing research, 18(1), 39-50.

Gerdenitsch, C., Korunka, C., \& Hertel, G. (2018). Need-Supply Fit in an ActivityBased Flexible Office: A Longitudinal Study During Relocation. Environment and Behavior, 50(3), 273-297.

Gibson, \& Lizieri, C. M. (1999). New business practices and the corporate property portfolio: How responsive is the UK property market? Journal of Property Research, 16(3), 201-218.

Gibson, V. (2001). In search of flexibility in corporate real estate portfolios. Journal of Corporate Real Estate, 3(1), 38-45.

Gibson, V. (2003). Flexible working needs flexible space? Towards an alternative workplace strategy. Journal of Property Investment \& Finance, 21(1), 12-22.

Gibson, V. A., \& Lizieri, C. M. J. J. o. P. R. (1999). New business practices and the corporate property portfolio: how responsive is the UK property market? , 16(3), 201-218.

Gillam, C., \& Oppenheim, C. (2006). Reviewing the impact of virtual teams in the information age. Journal of Information Science, 32(2), 160-175.

Gorgievski, M. J., van der Voordt, T. J., van Herpen, S. G., \& van Akkeren, S. (2010). After the fire: new ways of working in an academic setting. Facilities, 28(3/4), 206-224.

Greene, C., \& Myerson, J. (2011). Space for thought: designing for knowledge workers. Facilities, 29(1/2), 19-30. 
Haenlein, M., \& Kaplan, A. M. (2004). A beginner's guide to partial least squares analysis. Understanding statistics, 3(4), 283-297.

Hair, J. F. (2006). Multivariate data analysis (6th ed.). US: Prentice-Hall PTR.

Hair, J. F., Anderson, R. E., Babin, B. J., \& Black, W. C. (2010). Multivariate data analysis: A global perspective (Vol. 7). In: Upper Saddle River, NJ: Pearson.

Hair, J. F., Risher, J. J., Sarstedt, M., \& Ringle, C. M. (2019). When to use and how to report the results of PLS-SEM. European Business Review, 31(1), 2-24.

Hair Jr, J. F., Hult, G. T. M., Ringle, C., \& Sarstedt, M. (2017). A primer on partial least squares structural equation modeling (PLS-SEM). Thousand Oaks, CA: Sage publications.

Handel, M. J., \& Levine, D. I. (2004). Editors' introduction: The effects of new work practices on workers. Industrial Relations, 43(1), 1-43.

Harris, R. (2015). The changing nature of the workplace and the future of office space. Journal of Property Investment and Finance, 33(5), 424-435.

Harris, R. (2016). New organisations and new workplaces: Implications for workplace design and management. Journal of Corporate Real Estate, 18(1), 4-16.

Haynes, B. P. (2008). Impact of workplace connectivity on office productivity. Journal of Corporate Real Estate, 10(4), 286-302.

Haynes, B. P., Fawcett, W., \& Rigby, D. (2009). The interaction of activity, space and cost variables in office workstation sharing. Journal of Corporate Real Estate, 11(1), 38-51.

Henseler, J., \& Sarstedt, M. (2013). Goodness-of-fit indices for partial least squares path modeling. Computational Statistics, 28(2), 565-580.

Hills, R., \& Levy, D. (2014). Workspace design and fit-out: What knowledge workers value. Property Management, 32(5), 415-432.

Ho, C. M., \& Oladinrin, O. T. (2016). Evaluation of ethical codes implementation-a fuzzy approach. Facilities, 34(13/14), 924-955.

Hong Kong Stock Exchange. (2017). Hyperlinks to Listed Companies. Retrieved from https://goo.gl/qbRuZY

Insuarnce Authority. (2017). Register of Insurers. International Journal of Bank Marketing. Retrieved from https://goo.gl/2dBEux

Johnson, P. A., Bookman, A., Bailyn, L., Harrington, M., \& Orton, P. (2011). Innovation in ambulatory Care: A collaborative approach to redesigning the health care workplace. Academic Medicine, 86(2), 211-216.

Köffer, S., Junglas, I., Chiperi, C., \& Niehaves, B. (2014). Dual use of mobile IT and work-to-life conflict in the context of IT consumerization. Paper presented at the Thirty Fifth International Conference on Information Systems, Auckland.

Khamkanya, T., Heaney, G., \& McGreal, S. (2012). Scenario-based approach to office occupancy analysis. Property Management, 30(4), 333-350. 
Knapp, C., Vickroy, K., de Bruyn, L., \& Kwong, D. (2009). Are the myths of space utilization costing you more than you know? Journal of Corporate Real Estate, 11(4), 237-243.

Laing, A., Craig, D., \& White, A. (2011). Vision statement: High-performance office space. Harvard Business Review, 89(9).

Lee, S. Y., \& Brand, J. L. (2005). Effects of control over office workspace on perceptions of the work environment and work outcomes. Journal of Environmental Psychology, 25(3), 323-333.

Legislative Council. (2013). Press Release: supply of offices in Hong Kong. Retrieved from https://goo.gl/DsTQYq

Liang, Y., \& Kim, J. (1998). Demand for office space: neither feast nor famine. Real Estate Finance, 15(2), 37-44.

Lim, V. K., \& Teo, T. S. (2000). To work or not to work at home-An empirical investigation of factors affecting attitudes towards teleworking. Journal of Managerial Psychology, 15(6), 560-586.

Lingard, H. C., \& Rowlinson, S. (2006). Sample size in factor analysis: why size matters. Retrieved from

Lizieri, C., \& Satchell, S. (1997). Property company performance and real interest rates: a regime-switching approach. Journal of Property Research, 14(2), 85-97.

Lizieri, C. M. (2003). Occupier requirements in commercial real estate markets. Urban Studies, 40(5-6), 1151-1169.

Lockwood, A., \& Guerrier, Y. (1989). Flexible working in the hospitality industry: current strategies and future potential. International Journal of Contemporary Hospitality Management, 1(1).

Lowry, P. B., \& Gaskin, J. (2014). Partial Least Squares (PLS) Structural Equation Modeling (SEM) for Building and Testing Behavioral Causal Theory: When to Choose It and How to Use It. Professional Communication, IEEE Transactions on, $57(2), 123-146$.

Madsen, J. (2001). 2050 WorkSpace Odyssey. Buildings, 95(7), 64-66.

Malhotra, A., Majchrzak, A., \& Rosen, B. J. A. o. M. p. (2007). Leading virtual teams. 21(1), 60-70.

McGregor, W. (2000). The future of workspace management. Facilities, 18, 138-143.

McGregor, W. (2000). Preparing for an uncertain future. Facilities, 18(10/11/12), 402410.

Memon, A. H., Rahman, I. A., Aziz, A. A. A., \& Abdullah, N. H. (2013). Using structural equation modelling to assess effects of construction resource related factors on cost overrun. World Applied Sciences Journal, 21(5), 6-15.

Miller, G. N. (2012). Estimating office space per worker. Burnham-Moores Center for Real Estate University of San Diego. Retrieved from 
http://www.normmiller.net/wp-content/uploads/2012/08/Estimating-OfficeSpace-Requirements-Sept-12-2012.pdf.

Miller, G. N. (2014). Workplace trends in office space: implications for future office demand. Journal of Corporate Real Estate, 16(3), 159-181.

Minbaeva, D. B. (2005). HRM practices and MNC knowledge transfer. Personnel Review, 34(1), 125-144.

Neckerman, K. M., \& Kirschenman, J. (1991). Hiring strategies, racial bias, and innercity workers. Social problems, 38(4), 433-447.

Norman, G. R., \& Streiner, D. L. (2003). PDQ Statistics, 3rd Edition. Ontario: BC Decker Inc., .

Norusis, M. J. (2003). Linear mixed models in: SPSS 12.0 Statistical Procedures Comparison: Prentice Hall, Inc.

Ollo-López, A., Bayo-Moriones, A., \& Larraza-Kintana, M. (2011). The impact of country-level factors on the use of new work practices. Journal of World Business, 46(3), 394-403.

Ollo-Lopez, A., Bayo-Moriones, A., \& Larraza-Kintana, M. (2010). The relationship between new work practices and employee effort. Journal of Industrial Relations, 52(2), 219-235.

Osterman, P. (1994). How common is workplace transformation and who adopts it? ILR Review, 47(2), 173-188.

Oyedele, L. O. (2012). Avoiding performance failure payment deductions in PFI/PPP projects: model of critical success factors. Journal of Performance of Constructed Facilities, 27(3), 283-294.

Peggy, S. (2016, 19 May). More companies, including law firms, moving out of Hong Kong's CBD — but not just to escape high rents. South China Morning Post. Retrieved from https://goo.gl/py8 $\mathrm{NgC}$

Peponis, J., Bafna, S., Bajaj, R., Bromberg, J., Congdon, C., Rashid, M., . . Zimring, C. (2007). Designing space to support knowledge work. Environment and Behavior, 39(6), 815-840.

Pugsley, D., \& Haynes, B. (2002). An alternative use of space in government office accommodation. Facilities, 20(1/2), 34-40.

Qingxue, L. (2003). Understanding different cultural patterns or orientations between East and West. Investigationes Linguisticae, 9, 22-30.

Rabianski, J. S., \& Gibler, K. M. (2007). Office market demand analysis and estimation techniques: A literature review, synthesis and commentary. Journal of Real Estate Literature, 15(1), 37-56.

Rigdon, E. E. (2012). Rethinking partial least squares path modeling: In praise of simple methods. Long range planning, 45(5-6), 341-358.

Rigdon, E. E., Sarstedt, M., \& Ringle, C. M. (2017). On comparing results from CB- 
SEM and PLS-SEM: five perspectives and five recommendations. Marketing Zfp, 39(3), 4-16.

Robertson, K. (2000). Work transformation: Integrating people, space and technology. Facilities, 18, 376-382.

Rolfö, L. V. (2018). Relocation to an activity-based flexible office - Design processes and outcomes. Applied Ergonomics, 73, 141-150.

Romijn, G., Hakfoort, J., \& Lie, R. T. (1996). A model for office space per worker. University of Amsterdam: City University Business School.

Rosholm, M., Røed, M., \& Schøne, P. (2013). Are new work practices and new technologies biased against immigrant workers? International Journal of Manpower, 34(8), 995-1014.

Rybczynski, W. (1986). Home: A short history of an idea (Vol. 10): Viking New York.

Saari, A., Tissari, T., Valkama, E., \& Seppänen, O. (2006). The effect of a redesigned floor plan, occupant density and the quality of indoor climate on the cost of space, productivity and sick leave in an office building-A case study. Building and Environment, 41(12), 1961-1972.

Schøne, P. (2009). New technologies, new work practices and the age structure of the workers. Journal of Population Economics, 22(3), 803-826.

Skogland, M. A. C., \& Hansen, G. K. (2017). Change your space, change your culture: exploring spatial change management strategies. Journal of Corporate Real Estate, 19(2), 95-110.

Skyrme, D. J. (1994). Flexible working: building a lean and responsive organization. Long range planning, 27(5), 98-110.

Smith-Jackson, T. L., \& Klein, K. W. (2009). Open-plan offices: Task performance and mental workload. Journal of Environmental Psychology, 29(2), 279-289.

Tagliaro, C., \& Ciaramella, A. (2016). Experiencing smart working: a case study on workplace change management in Italy. Journal of Corporate Real Estate, 18(3), 194-208.

Virginia, G., \& Colin, L. (2001). Friction and inertia: business change, corporate real estate portfolios and the UK office market. Journal of Real Estate Research, 22(1-2), 59-80.

Waber, B., Magnolfi, J., \& Lindsay, G. (2014). Workspaces that move people. Harvard Business Review, 92(10), 121-177.

Wadu Mesthrige, J. (2014). An urban growth model of office property development: The case of Hong Kong. Facilities, 32(11/12), 647-674.

Watson, R., \& Thompson, D. R. (2006). Use of factor analysis in Journal of Advanced Nursing: literature review. Journal of Advanced Nursing, 55(3), 330-341.

Williams, B., Brown, T., \& Boyle, M. (2012). Construct validation of the readiness for interprofessional learning scale: a Rasch and factor analysis. Journal of 
Interprofessional Care, 26(4), 326-332.

Yu, A. T., \& Shen, G. Q. (2013). Critical success factors of the briefing process for construction projects. Journal of Management in Engineering, 31(3), 04014045.

Table 1: NWPs Extracted form Literature

\begin{tabular}{|c|c|c|}
\hline ID & Labels & Sources \\
\hline NWP1 & $\begin{array}{l}\text { Flexible working hours } \\
\text { (part-time, flexitime) }\end{array}$ & $\begin{array}{l}\text { (Arvanitis, Seliger, \& Stucki, 2016); (Askenazy \& Caroli, } \\
\text { 2010); (Bean \& Hamilton, 2006); (Colteryahn \& Davis, 2004) }\end{array}$ \\
\hline NWP2 & $\begin{array}{l}\text { Job autonomy/agile } \\
\text { working }\end{array}$ & $\begin{array}{l}\text { (Bayo-Moriones, Billon, \& Lera-López, 2017); (Bell \& } \\
\text { Anderson, 1999) }\end{array}$ \\
\hline NWP3 & $\begin{array}{l}\text { Telecommuting/telework } \\
\text { ing }\end{array}$ & $\begin{array}{l}\text { (Gibson \& C. M. Lizieri, 1999); (Harris, 2016); (Robertson, } \\
\text { 2000) }\end{array}$ \\
\hline NWP4 & Training & $\begin{array}{l}\text { (Arvanitis et al., 2016); (Johnson, Bookman, Bailyn, } \\
\text { Harrington, \& Orton, 2011) }\end{array}$ \\
\hline NWP5 & $\begin{array}{l}\text { Job rotation/blended } \\
\text { working }\end{array}$ & $\begin{array}{l}\text { (Askenazy \& Caroli, 2010); (Osterman, 1994); (Ollo-Lopez, } \\
\text { Bayo-Moriones, \& Larraza-Kintana, 2010) }\end{array}$ \\
\hline NWP6 & Networking & (Colteryahn \& Davis, 2004); (Johnson et al., 2011) \\
\hline NWP7 & Delayering & (Colteryahn \& Davis, 2004); (Gibson \& C. M. Lizieri, 1999); \\
\hline NWP8 & Flexible workspaces & $\begin{array}{l}\text { (Blok, Groenesteijn, Schelvis, \& Vink, 2012); (Bean \& } \\
\text { Hamilton, 2006) }\end{array}$ \\
\hline NWP9 & $\begin{array}{l}\text { Enhanced/improved } \\
\text { communication }\end{array}$ & $\begin{array}{l}\text { (Ollo-Lopez et al., 2010); (Ollo-López, Bayo-Moriones, \& } \\
\text { Larraza-Kintana, 2011) }\end{array}$ \\
\hline NWP10 & $\begin{array}{l}\text { Teamwork coupled with } \\
\text { team autonomy }\end{array}$ & $\begin{array}{l}\text { (Askenazy \& Caroli, 2010); (Bayo-Moriones et al., 2017); } \\
\text { (Johnson et al., 2011) }\end{array}$ \\
\hline
\end{tabular}




\begin{tabular}{llll}
\hline ID & Labels & \multicolumn{1}{c}{ Sources } \\
\hline NWP11 & $\begin{array}{l}\text { Multitasking } \\
\text { multiskilling }\end{array}$ and & (Rosholm, Røed, \& Schøne, 2013); (Schøne, 2009) \\
NWP12 & $\begin{array}{l}\text { Total } \\
\text { Management }\end{array}$ & Quality & (Gibson \& C. M. Lizieri, 1999); (Osterman, 1994); \\
& (Askenazy \& Caroli, 2010) \\
NWP13 & Quality Circles & (Osterman, 1994); (Askenazy \& Caroli, 2010) \\
NWP14 & Staff density & (Gibson \& C. M. Lizieri, 1999); (Blok et al., 2012) \\
NWP15 & Selective hiring & (Cristini, Gaj, Labory, \& Leoni, 2002); (Bean \& Hamilton, \\
& & 2006) \\
NWP16 & Activity-based working & (Rolfö, 2018); (Fincke, Harth, \& Mache, 2018); \\
NWP17 & Knowledge workers & (Bean \& Hamilton, 2006); (Johnson et al., 2011) \\
NWP18 & Ad-hoc task-forces & (Eriksson, 2003); (Cristini et al., 2002) \\
NWP19 & Outsourcing & (Gibson \& C. M. Lizieri, 1999); (Lockwood \& Guerrier, \\
& & 1989) \\
NWP20 & Profit sharing, or pay-for- & (Handel \& Levine, 2004); (Cristini et al., 2002) \\
& performance & \\
\hline
\end{tabular}


Table 2: Respondents' background information

\begin{tabular}{llcc}
\hline Item & Category & Count & $(\%)$ \\
\hline Respondent's position & Professional staff & 70 & 66.7 \\
& Technical staff & 3 & 2.9 \\
& Division head and above & 13 & 12.4 \\
& Clerical staff & 9 & 8.6 \\
& Other & 10 & 9.5 \\
& & & \\
Respondent's experience & $0-5$ years & 14 & 13.3 \\
& 6-10 years & 22 & 21.0 \\
& 11-15 years & 28 & 26.7 \\
& 16-20 years & 19 & 18.1 \\
& Above 20 years & 22 & 21.0 \\
& & & \\
Type of firm & Finance & 35 & 33.3 \\
& Insurance & 4 & 3.8 \\
& Real Estate & 46 & 43.8 \\
& Business and consultancy service & 20 & 19.0 \\
Types of office & Enclosed private & 24 & 22.9 \\
& Enclosed shared & 2 & 1.9 \\
& Cubicles with high partitions & 7 & 6.7 \\
& Cubicles with low partitions & 27 & 25.7 \\
& Open office with limited or no & 45 & 42.9 \\
partitions & & \\
\hline
\end{tabular}


Table 3: Descriptive statistics of NWP factors

\begin{tabular}{|c|c|c|c|c|}
\hline ID & em description & Mean & S.D & S.E \\
\hline NPI1 & $\begin{array}{l}\text { The firm allows flexible working arrangement (e.g. part-time, } \\
\text { flexitime, overtime) for employees }\end{array}$ & 3.74 & 193 & 16 \\
\hline NWPI2 & $\begin{array}{l}\text { ows employees' discretions in the way their work is } \\
\text { job autonomy) }\end{array}$ & 3.70 & 1.055 & 0.103 \\
\hline NWPI16 & eeting spaces of a greater variety & 3.68 & 1.114 & 0.109 \\
\hline NWPI3 & $\begin{array}{l}\text { Employees can work from distance - at home, at client's place or } \\
\text { on-the-move (telecommuting/telework) }\end{array}$ & 3.60 & 1.182 & 0.115 \\
\hline NWPI14 & $\begin{array}{l}\text { There are fewer number of workstations than the workers (staff } \\
\text { density) }\end{array}$ & 3.54 & 1.352 & 0.132 \\
\hline NWPI8 & $\begin{array}{l}\text { There is regular change and sharing of workspaces (flexible } \\
\text { workspace) }\end{array}$ & 3.48 & 1.225 & 0.120 \\
\hline WPI17 & ore knowledge workers than manual workers & 3.44 & 1.270 & 0.124 \\
\hline WPI10 & There & 3.35 & 52 & 0.112 \\
\hline NWPI7 & $\begin{array}{l}\text { ignificant effort to make the organisation less hierarchical } \\
\text { g) }\end{array}$ & 3.32 & 1.213 & 0.118 \\
\hline NWPI18 & $\begin{array}{l}\text { engage in periodic problem resolution (Ad-hoc task- } \\
\text { oject-organization) }\end{array}$ & 3.30 & 1.506 & 0.147 \\
\hline WPI19 & side (Outsourcing) & 3.27 & 1.235 & 0.120 \\
\hline JWPI11 & $\begin{array}{l}\text { hods to perform more than one task } \\
\text { ng) }\end{array}$ & 3.27 & 49 & 02 \\
\hline NWPI13 & $\begin{array}{l}\text { Group of employees meets regularly to discuss work-related } \\
\text { problems (Quality Circles) }\end{array}$ & 3.16 & 1.257 & 0.123 \\
\hline IWPI4 & The fi & 3.14 & 1.023 & 0.100 \\
\hline NWPI12 & $\begin{array}{l}\text { Every member of staff is committed to maintaining high standards } \\
\text { of work (TQM). }\end{array}$ & 3.12 & 1.124 & 0. \\
\hline NWPI6 & $\begin{array}{l}\text { There are arrangements for staff to work on projects with } \\
\text { employees of other firms (networking) }\end{array}$ & 3.07 & 1.068 & 0.104 \\
\hline NWPI9 & $\begin{array}{l}\text { Employees are given chances to express their opinions } \\
\text { (enhanced/improved communication)) }\end{array}$ & 3.03 & 1.274 & 0.124 \\
\hline NWPI20 & $\begin{array}{l}\text { Non-traditional compensation is practiced (profit sharing, or pay- } \\
\text { for-performance) }\end{array}$ & 3.00 & 1.043 & 0.102 \\
\hline NWPI5 & $\begin{array}{l}\text { Employees are arranged to work across divisions or sectors within } \\
\text { the firm (job rotation) }\end{array}$ & 2.94 & 1.064 & 0.104 \\
\hline NWPI15 & $\begin{array}{l}\text { Psycho-behavioural test is used during recruitment process } \\
\text { (selective hiring) }\end{array}$ & 2.81 & 1.136 & 0. \\
\hline
\end{tabular}


Table 4: Measure of the suitability of EFA

\begin{tabular}{|c|c|c|c|}
\hline \multicolumn{4}{|c|}{ KMO and Bartlett's Test } \\
\hline Kaiser-Me & r-Olkin & easure of Sampling Adequacy. & .828 \\
\hline \multirow{3}{*}{$\begin{array}{l}\text { Bartlett's } \\
\text { Sphericity }\end{array}$} & \multirow{3}{*}{ Test } & Approx. Chi-Square & 1166.276 \\
\hline & & Df & 190 \\
\hline & & Sig. & .000 \\
\hline
\end{tabular}

Table 5: Factor loadings and cross-loadings

\begin{tabular}{|c|c|c|c|c|c|}
\hline ID & $\mathrm{em}$ & 1 & 2 & 3 & 4 \\
\hline WPI1 & $\begin{array}{l}\text { The firm allows flexible working arrangement (e.g. part- } \\
\text { time, flexitime, overtime) for employees }\end{array}$ & .786 & .025 & .228 & .071 \\
\hline WPI2 & $\begin{array}{l}\text { The firm allows employees' discretions in the way their } \\
\text { work is carried out (job autonomy) }\end{array}$ & .765 & .048 & .284 & 169 \\
\hline IWPI3 & $\begin{array}{l}\text { Employees can work from distance - at home, at client's } \\
\text { place or on-the-move (telecommuting/telework) }\end{array}$ & .825 & .185 & .040 & $\begin{array}{l}-.07 \\
0\end{array}$ \\
\hline WPI14 & $\begin{array}{l}\text { ver number of workstations than the workers } \\
\text { ) }\end{array}$ & .951 & .075 & .161 & .119 \\
\hline WPI15 & $\begin{array}{l}\text { Psycho-behavioural test is used during recruitment process } \\
\text { (selective hiring) }\end{array}$ & .176 & .542 & .093 & 21 \\
\hline WPI6 & $\begin{array}{l}\text { There are arrangements for staff to work on projects with } \\
\text { employees of other firms (networking) }\end{array}$ & -.189 & .629 & .219 & 218 \\
\hline NPI4 & The firm invests in staff training & .133 & .944 & .371 & .314 \\
\hline WPI10 & $\begin{array}{l}\text { There is extensive use of team work coupled with team } \\
\text { autonomy }\end{array}$ & .155 & .156 & .795 & .324 \\
\hline WPI8 & $\begin{array}{l}\text { There is regular change and sharing of workspaces } \\
\text { (flexible workspace) }\end{array}$ & .264 & .115 & .573 & .345 \\
\hline WPI9 & $\begin{array}{l}\text { Employees are given chances to express their opinions } \\
\text { (enhanced/improved communication)) }\end{array}$ & -.009 & .394 & .798 & .097 \\
\hline NWPI18 & $\begin{array}{l}\text { Employees engage in periodic problem resolution (Ad-hoc } \\
\text { task-forces or project-organization) }\end{array}$ & .249 & .146 & .868 & .013 \\
\hline WPI11 & $\begin{array}{l}\text { Employee use multiple methods to perform more than one } \\
\text { task (multitasking and multiskilling) }\end{array}$ & .242 & .304 & .399 & .992 \\
\hline NPI17 & There are more knowledge workers than manual workers & .25 & .030 & .246 & .668 \\
\hline
\end{tabular}


Table 6: Construct Reliability and Validity

\begin{tabular}{llll}
\hline \multicolumn{1}{c}{ Factors } & $\begin{array}{l}\text { Cronbach's } \\
\text { Alpha }\end{array}$ & $\begin{array}{l}\text { Composite } \\
\text { Reliability }\end{array}$ & $\begin{array}{l}\text { Average Variance } \\
\text { Extracted (AVE) }\end{array}$ \\
\hline Flexible arrangement & 0.887 & 0.901 & 0.697 \\
Multitasking knowledge workers & 0.724 & 0.829 & 0.715 \\
Teamwork and communication & 0.787 & 0.848 & 0.588 \\
Training and selective hiring & 0.648 & 0.759 & 0.527 \\
\hline
\end{tabular}

Table 7: Discriminant Validity using Fornell-Larcker Criterion

\begin{tabular}{llllll}
\hline \multicolumn{1}{c}{ Factors } & $\begin{array}{l}\text { Average } \\
\text { space } \\
\text { usage }\end{array}$ & $\begin{array}{l}\text { Flexible } \\
\text { arrangement }\end{array}$ & $\begin{array}{l}\text { Multitasking } \\
\text { knowledge } \\
\text { workers }\end{array}$ & $\begin{array}{l}\text { Teamwork and } \\
\text { communication }\end{array}$ & $\begin{array}{l}\text { Training } \\
\text { and } \\
\text { selective } \\
\text { hiring }\end{array}$ \\
\hline $\begin{array}{l}\text { Average space } \\
\text { usage }\end{array}$ & 1.000 & & & & \\
$\begin{array}{l}\text { Flexible } \\
\text { arrangement }\end{array}$ & 0.104 & 0.835 & & & \\
$\begin{array}{l}\text { Multitasking } \\
\text { knowledge }\end{array}$ & 0.102 & 0.384 & 0.846 & & \\
$\begin{array}{l}\text { workers } \\
\begin{array}{l}\text { Teamwork and } \\
\text { communication } \\
\text { Training and } \\
\text { selective hiring }\end{array}\end{array}$ & 0.112 & 0.321 & 0.567 & 0.767 & \\
\hline
\end{tabular}


Table 8: Path Coefficients

Path relationships

Original $\mathrm{T}$ Statistics $\mathrm{P}$

Sample $\quad(|\mathrm{O} / \mathrm{STDEV}|) \quad$ Values

(O)

Flexible arrangement -> Average space usage

0.079

0.079

0.567

0.571

Multitasking knowledge workers -> Average space usage

0.085

0.625

0.532

Teamwork and communication -> Average space usage

0.233

1.279

0.201

Training and networking $->$ Average space usage

$-0.3612 .065^{*}$

0.039 


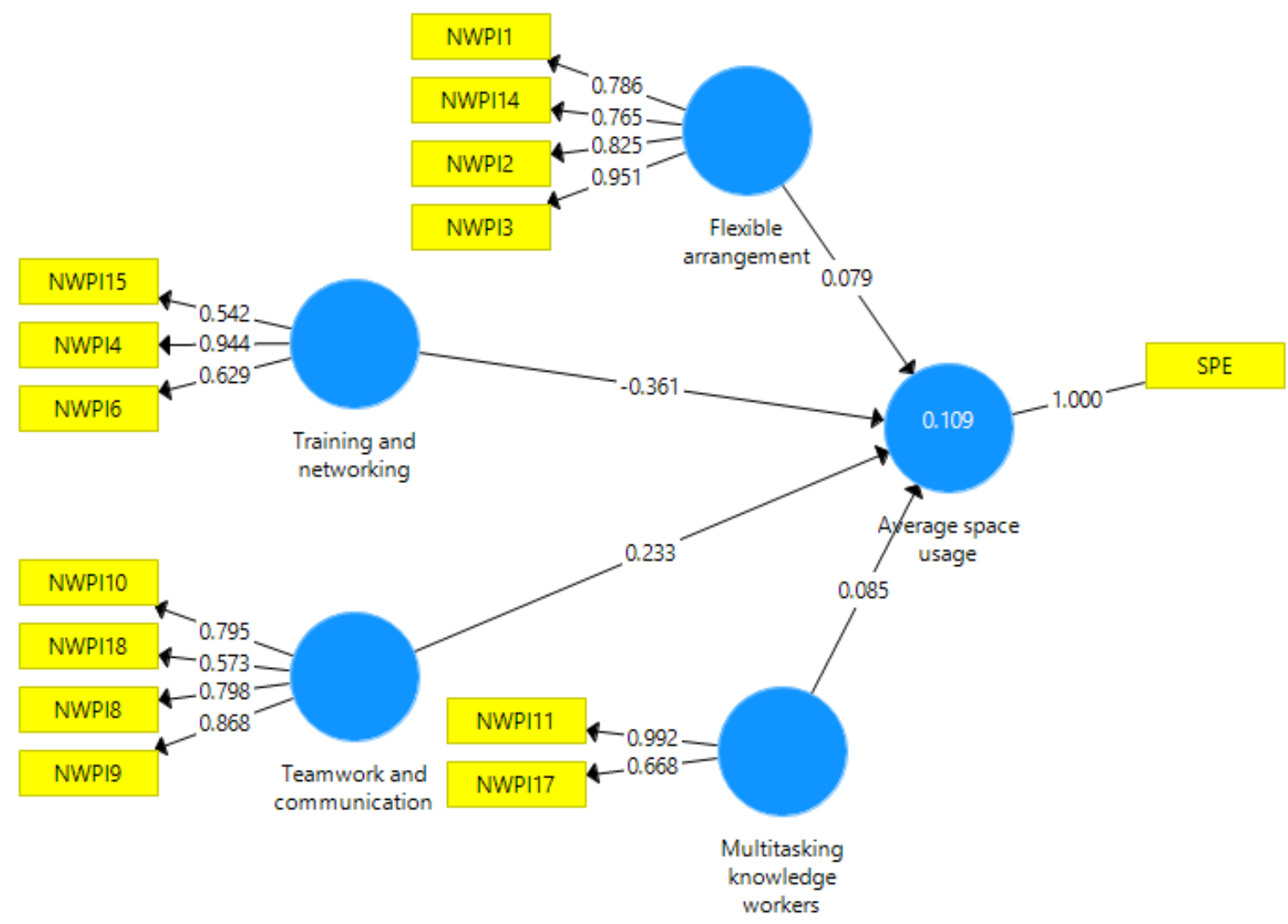

Figure 1: Structural model of the NWP influencing space usage Note: SPE = space per employee 